\title{
Investment Appeal and Research \& Development Capacity of the Regions
}

\author{
${ }^{1}$ L.I. Arsentyeva, ${ }^{2}$ I.S. Bulnina, ${ }^{3}$ I.A. Kabasheva, ${ }^{4}$ A.G. Khairullina \\ 1,2,3,4 Kazan Federal University, Kazan, 420008, Russia
}

Received: 15th December 2017, Accepted: 20th December 2017, Published: 31st December 2017

\begin{abstract}
The formation of regions' investment appeal gives the opportunity to create the conditions for economic and social development of the territories and the state as a whole. This issue should be considered from several points. It is worth noting that each region has its own characteristics and a growth potential. It is evident that a number of territories could take participation in the competition for the opportunity to obtain investment funds. At the same time for the state's economy there is a need of the development and maintenance of existing scientific, technological and industrial centers in the developed regions as drivers of an industrial and scientific and technological growth. There is a need for a system accounting of wide range of conditions and criteria within the region. The presented approach will not only determine perspective directions of investment, but also calculate the planned results and assess the synergies of investment programmes implementation in different areas.
\end{abstract}

Keywords: Investment Appeal, Investment Potential, The Region's Potential, Investment Fund, Intellectual Capital

\section{Introduction}

Investment appeal is a system of significant conditions and characteristics of the investment object. It is a dynamic characteristic which in certain periods fixes the results of the object's development and changes. In the case of working out and application of the investment attractiveness development model one can predict the results of future events.

Investment appeal of the territory represents a criterion reflecting the difference of investment funds and capital outflows.

\section{Theory}

Formation of regions' investment appeal makes it possible to create the conditions for economic and social development of the territories and the state as a whole. This issue should be considered from several points. The first point is from the position of the state. The creation of favorable conditions for attracting investment resources and their planning, target-oriented development is a fundamental basis of the economy development as a whole. Thus, the objective of regions' investment appeal formation is determined. It is a comprehensive socio-economic development of the territory, with a possibility to enhance the regional scientific-technical and production reserve. Increasing the pace of manufacturing growth creates the conditions for a number of socio-economic indicators change which characterize territories development.

It is worth noting that each region has its own characteristics and a growth potential. It is evident that a number of the territories could enter into competition for the opportunity to obtain investment funds. On this basis, it becomes clear that the direct government regulation and public policy regarding individual territories could play a key role. The authors assume that in relative identity of development indicators and areas potential the support can be directed to the region, which should be sustained with the aim of overall alignment of the economic situation in the country. According to the authors the most striking example in the Russian Federation may serve a state support of the Crimea.

At the same time for the state's economy there is a need for the development and maintenance of existing scientific, technological and industrial centers in the developed regions as drivers of industrial and scientific and technological growth. There is a need for a system accounting of conditions wide range and criteria within the region.

\section{Result and Discussion}

Among those criteria, the authors consider the level of development in the sphere of industry, education and science. Taking into account the current trends, we can talk about keeping and the development of large industrial and scientific regional structures, about their innovative activity as a fundamental factor in the development of the economy as a whole.

The criterion of innovation activity of enterprises is determined by its innovative potential, which structurally and systemically contains the following components, which are depicted in Figure 1. 
Helix Vol. 8(1): 2847-2851

\begin{tabular}{|c|c|c|c|}
\hline Intellectual Potential & Market Potential & Logistical Potential & Organizational Potential \\
\hline $\begin{array}{c}\text { Value enclosed in } \\
\text { knowledge }\end{array}$ & $\begin{array}{c}\text { Value enclosed in a } \\
\text { relationship }\end{array}$ & $\begin{array}{c}\text { Values enclosed in } \\
\text { material capabilities }\end{array}$ & $\begin{array}{c}\text { Value enclosed in } \\
\text { intellectual property } \\
\text { objects, structures and } \\
\text { processes }\end{array}$ \\
\hline
\end{tabular}

Fig.1. Components of the Innovation Potential

Thus, the directions are determined, their development should contribute to more effective use of innovative capacity of regional enterprise, as the basis of the entity innovation activity increasing.

As an example, let's consider the current situation in the Russian Federation and in the Republic of Tatarstan as a subject of the Federation.

The existing regional development rankings on the example of the Russian Federation reflect the criteria related to the change in the level of risk in the region, for example, in "investment attractiveness of regions-2014" [1], compiled by the rating agency "Expert RA" (2015).

One of the main aspects of the assessing rating is an investment potential. In the existing approach to ranking the potential shows what share the region has in the Russian market.

Let's consider the current situation and the existing ratings of regions investment attractiveness. There is no use for the regions to wait for significant support from the Federal Centre. Share of federal transfers in total income of the regions on the basis of data for 9 months of 2015 , was reduced to $18 \%$. We are speaking about regions, which can suffer most of all, where the proportion of own revenues in the budget is minimal, including Republic of Siberia and the North Caucasus.

The number of subjects which performed their budgets with deficit in 2014 increased by $13 \%$, to 77 , in 37 regions the budget deficit exceeded threshold$15 \%$ of their own income. In the third quarter of 2015 , social obligations reached $64 \%$ of the total costs of the regional budgets.

To cover the budget deficit regions are forced to rack up the debt. In the third quarter of 2015 it was $33.8 \%$ of their own income. From its total volume $38 \%$ there are short-term bank loans with high interest rates, which adversely affected the value of financial risks. The share of budgetary loans accounts for only $31 \%$. The number of regions with a national debt share of more than $50 \%$ in their own income in the 3rd quarter of 2015 has risen to 41, compared with 34 for the same period last year [1].

The overall picture of the Russian Federation shows a decrease of a number of indicators. According to the authors, this rating should be improved, taking into account the proposals presented above (in the part of the human and intellectual capital accounting). Thus, the overall picture will be changed dynamically to the positive way to make decisions to invest into the regions of the Russian Federation, as the focus of the review didn't include one of the most significant indicators of the research and development sector. The indicators of regions' investment appeal were remained undervalued. Let's consider as the example the Republic of Tatarstan. Risk grade 11 (2015) 7 (2014)-there has been an increase in rank (taken place in the rating among all subjects of the Russian Federation).

Rank of potential in 2015- 6. It is a high figure in comparing with other regions of the Russian Federation. It is planned rate of the region place in the overall list of subjects of the Russian Federation. Average weighted index of risk in 2015- 0.183.

Changing of the risk index, 2014 to2015, increasing (+), decreasing (-) 0.000. The change in index didn't happen, though, in comparing with other regions the Republic of Tatarstan has shifted in the list of regions (for 4 points).

Changing of risk rank, 2015 to 2014 -4 [1].

The region under consideration belongs to the group of medium capacity-minimal risk.

On the investment potential criterion, the Republic of Tatarstan expressed the following indicators:

Potential rank in 2014. -"6". Potential rank in 2015 - "6". The situation remained unchanged.

The share in the Russian potential in 2015, \%-2.476. The change in share of potential, 2015 to 2014 "0.041". There is some decrease in capacity.

Let's compare this region's indicators with other territories of the Russian Federation. 
Table 2. The Russian Federation Subjects' Indicators Comparison.

\begin{tabular}{|c|c|c|c|c|c|c|c|c|c|c|c|c|}
\hline \multicolumn{2}{|c|}{ 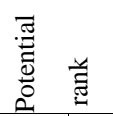 } & \multirow[b]{2}{*}{ 尊 } & \multirow{2}{*}{ Federation subjects } & \multirow{2}{*}{ 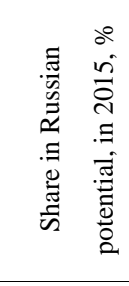 } & \multirow{2}{*}{ 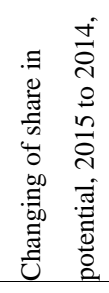 } & \multicolumn{5}{|c|}{ Rank components of the investment potential in 2015} & \multirow{2}{*}{\multicolumn{2}{|c|}{ 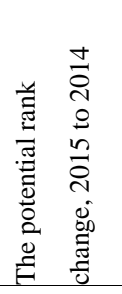 }} \\
\hline$\stackrel{n}{\stackrel{\sim}{\sim}}$ & $\stackrel{\nabla}{\vec{\Delta}}$ & & & & & 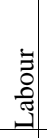 & 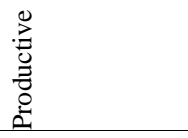 & 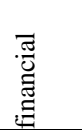 & 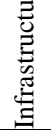 & 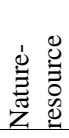 & & \\
\hline 1 & 1 & 10 & Moscow & 14,569 & $-0,749$ & 1 & 1 & 1 & 1 & 82 & & 0 \\
\hline 3 & 3 & 4 & St. Petersburg & 4,780 & $-0,685$ & 2 & 3 & 2 & 2 & 49 & & 0 \\
\hline 4 & 4 & 1 & The Krasnodar Territory & 2,788 & 0,108 & 4 & 7 & 4 & 5 & 27 & & 0 \\
\hline 5 & 5 & 21 & The Sverdlovsk Region & 2,651 & 0,024 & 8 & 5 & 5 & 46 & 12 & & 0 \\
\hline 6 & 6 & 11 & The Republic of Tatarstan & 2,476 & $-0,041$ & 6 & 6 & 6 & 19 & 40 & & 0 \\
\hline 15 & $\begin{array}{l}1 \\
6\end{array}$ & 19 & The Novosibirsk Region & 1,590 & 0,011 & $\begin{array}{l}1 \\
2\end{array}$ & 20 & 16 & 47 & 39 & & 1 \\
\hline 29 & $\begin{array}{l}2 \\
6\end{array}$ & 81 & The Republic of Dagestan & 1,066 & $-0,044$ & $\begin{array}{l}1 \\
9\end{array}$ & 57 & 18 & 35 & 41 & & -3 \\
\hline 64 & $\begin{array}{l}6 \\
3\end{array}$ & 41 & The Novgorod Region & 0,515 & 0,011 & $\begin{array}{l}6 \\
9\end{array}$ & 60 & 64 & 42 & 76 & & -1 \\
\hline
\end{tabular}


The given rankings reflect the place in overall listing among the entities of the Russian Federation. Analyzing the ranks, we get a picture in which it is possible to determine the most promising investment destinations. For example, the rank of naturalresource component of the investment potential of Moscow is negligible ( 82 positions). At the same time the highest value of potential is indicated on such elements as the labour potential, production, finance, and infrastructure.

Considering the figures of the given regions and entities of the Russian Federation, we can note the following:

Central and North West parts (presented by Moscow, St. Petersburg) do not have the resource potential in the significant industrial scale, but have considerable capacity in the development of financial, production and infrastructure component. These territories are large consumers and processors of raw materials.

The Krasnodar territory is presented by high ranks. According to the authors this is a confirmation of the provisions about special support of the region for the benefit of the state. The Winter Olympics Games in Sochi in 2015, just were as a catalyst for the development of Krasnodar territory.

The territories of the Urals and the Volga region are traditionally strong productive sectors, and therefore the investment processes should be oriented to these directions.

The eastern part of the Russian Federation (Siberia), which is presented by the indicators of the Novosibirsk region, has points of growth in employment, production and financial capabilities. The infrastructure capacity, submitted by 47 th position determines the feasibility of investment projects development in this area. Indirectly on the opportunities of growth beginning points the rate of potential rank change of 2015 to $2014(+1)$.

Data on the Republic of Dagestan shows presence of labour, but this resource is not matched by the rate of productive capacity. In this case the investment decisions and efforts should be directed to new industries creation.

The Novgorod region's data indicates the feasibility of investment projects implementation in order to upgrade existing facilities.

Such approach will not only determine perspective directions of investment, but also to calculate the planned results and assess the synergies of the investment programmes implementation in different areas [3].

The authors consider that the interests of all participants in the investment process will improve the existing rating records. For example, in the assessment of investment potential it is necessary to take into account the human and intellectual capital that can be expressed and accounted for businesses operating in the region. The human and intellectual capital is directly and immediately connected with the qualification of enterprise's personnel [2].

At the same time one should note that the Republic of Tatarstan is different from the most of the regions in special growth's reserve. In addition to powerful potential there is a high scientific and technical potential, which is expressed not only in technology, but also in a significant number of highly skilled workers in industry, science and education. An additional factor for regional risk reduction, according to the authors, is a system of measures which can provide events on international scale (Universiade 2013, World Championships). The combination of presented conditions provides the basis for the creation and development of enterprises on the territory of the Republic of Tatarstan, as the region has a certain level of publicity and recognition of the region which has an extensive database of highly qualified specialists, systems of training and retraining, including management training.

At the present stage of decision-making there are no mechanisms on investment attracting and the investment programmes implementation, which can determine what size of investment and the period should be given to these ot those aspects, influencing the future way of region's investment appeal development: investment in research and development, reducing the investment risks, the development and modernization of existing production facilities, development of environmental programmes, improving the efficiency of intellectual capacity using. How to increase the efficiency of investment using, taking into account the possibility of synergy effect from the investments' directions.

\section{Conclusion}

The authors suggest the approach given by Ustinova L.N. (2015) [3], its practical application is in assessing the capacity of a number of businesses and industries of the Russian Federation. In particular, there can be used the algorithm of assessing the effectiveness of the use of enterprises' innovative potential using as the basis of the region's innovation potential formation, which has an impact on the level of region's investment appeal. The proposed algorithm consistently and systematically accounts the diagnostics of innovation potential, prediction of the priority investment direction to the elements of innovative potential, development and implementation of a strategy for innovation capacity building, direct evaluation of the results.

According to the authors, the next stage of regions' investment appeal development must be the territorial programme of science and industry 
development. It is necessary to form the programme, defining the role and place of each enterprise, project in the overall structure of the regional development. It's better to take into account the final results of enterprises' economic activities in the form of goods and services, net income, but to form a regional picture on the directions which are developed in each organization. For example, the programme of technical and technological capacity creation of all enterprises can be the basis for the territorial programme of competitiveness, taking into account the specificity of local productions and applied scientific and technological base. Production and sales of new products, as part of the territorial programme are formed on the basis of existing productions. Thus, it is possible to create a complete picture of the prospective regional development in order to attract investment resources on a certain territory broken down by enterprises. The investor has an opportunity to assess not only the proposed project, production (as an object of investment), but also get a chance to assess the investment climate in the region.

In general, it will give the opportunity to form a model of regional development in order to attract investment resources and their effective management, which are targeted.

In conclusion it should be noted that determination of the level of region's investment appeal is systemic and has a significant impact on the development of both the region and the state as a whole. It serves as the basis for decision-making on whether to invest. Existing methods of investment appeal evaluation of the territories should be complemented by mechanisms of synergy in the risk accounting. Additionally, it is important to identify and take into account the level of intellectual and human capital in the considered regions. Currently, there are techniques to assess the innovation potential of enterprises that have already included the above criteria. These techniques can be adapted to calculate the estimation parameters of regions' investment appeal. Taking into account the current state of the economy, its innovative orientation one should take into account the level of innovation activity of enterprises, science and technology base and education system, upgrading courses, training and retraining of specialists.

\section{Acknowledgements}

The work is performed according to the Russian Government Program of Competitive Growth of Kazan Federal University.

\section{References}

1. Investment appeal of the regions - 2014, Rating agency «Expert RA» (RAEX) (2014).

2. Ustinova L.N., Ustinov A.E. Studying the impact of intellectual capital at industrial enterprises on their market capitalization. Asian Social Science; Vol. 10, No. 20; 2014.

3. Ustinova L.N., "Improving the assessment of innovation potential using efficiency. Dissertation, 2014.

4. Larionova N., Varlamova J. Correlation analysis of macroeconomic and banking system indicators // Procedia Economics and Finance 14 ( 2014 ) 359-366.

5. Larionova N., Varlamova J. Factors of Economic Innovative Development: Cross-Country Evidence // Mediterranean Journal of Social Sciences. Vol 5, No 18 (2014). - PP.349-354.

6. Larionova N., Varlamova J., Singatullina G. The Trends of Household Economic Behavior in Emerging Countries of Europe // Procedia Economics and Finance 15 (2014).-421-429. 